\title{
Parametric study on the behaviour of bagasse ash-calcium carbide residue stabilized soil
}

\author{
John Tri Hatmoko ${ }^{1, *}$ and Hendra Suryadharma ${ }^{1}$ \\ ${ }^{1}$ Department of Civil Engineering, Universitas Atma Jaya Yogyakarta, Jln. Babarsari No. 44 \\ Yogyakarta
}

\begin{abstract}
A series of experiments including unconfined compression tests, three-axial tests, compaction tests, and split tensile tests were undertaken to investigate the influence of compaction parameters on the behaviour of bagasse ash-calcium carbide residue stabilized soil. A preliminary study on soil with the addition of $4 \%, 6 \%, 8 \%, 10 \%$, and $12 \%$ calcium carbide residue established that the lime fixation point (LFP) was $4 \%$. Then $9 \%$ bagasse ash was added to soil with $4 \%$ calcium carbide residue, and the cation exchanges and pozzolanic reactions were investigated. The addition of calcium carbide residue to bagasse ash stabilized soil caused short-term changes due to cation exchange reactions, including an increase in the friction angle and cohesion in the stabilized soil. In addition, due to the short-term reaction, the maximum stiffness in three-axial tests occurred in the samples moulded with less than their optimum moisture content (OMC), whereas the peak strength occurred in the samples moulded at their OMC. After a 28-day curing period, pozzolanic reactions improved significantly the three-axial peak strength and stiffness of the stabilized soil, and the maximum three-axial shear strength and stiffness occurred in the samples prepared below their OMC.
\end{abstract}

\section{Introduction}

Soil stabilization with lime, cement, fly ash, bagasse ash, rice husk ash, and combinations of fly ash-cement, bagasse ash-lime, and rice husk ash-lime have been investigated by many researchers [1-7]. The effect of the combination of bagasse ash-calcium carbide residue on the shear strength of expansive soil has been performed [8]. Research concerning fly ash and lime for soil improvement has been conducted in recent decades by many researchers [9-15]. The physical and chemical performance of both short-term and long-term reactions in soil-lime-fly ash mixtures has been reported in the literature [1619]. The previous studies have discussed the effects of the temperature and curing period and the proportion of lime and fly ash on the unconfined compression and tensile strength of soil. However, they were performed without a compaction process. Because in practical work such as highways, airfields, and dam construction soil are always compacted, it is important to study the effects of the compaction parameters (maximum dry density and

\footnotetext{
*Corresponding author : john@mail.uajy.ac.id
} 
optimum moisture content) on the shear behaviour of bagasse ash-calcium carbide residue (CCR) of stabilized soil.

To provide information on the stress-strain behaviour of calcium carbide residuebagasse ash stabilized soil due to compaction, soil mixed with bagasse ash and calcium carbide was used in this research. A series of laboratory experiments were performed to define the response of stabilized soil to static compaction. The changes of mechanical properties because of the replacement of soil with bagasse ash and changes of behaviour due to the addition of calcium carbide are also analyzed. This research then provides the results of laboratory experiments to investigate the short-term and long-term effects on the behavior of stabilized soil directly after compaction.

\section{Research methodology}

\subsection{Materials}

The soil sample used in this study is local soil taken from Wates, Kulonprogo Regency, the Special Region of Yogyakarta. It is low cohesion-high plasticity red clay. According to the Unified Soil Classification System (USCS), the soil is classified as high plasticity clay $(\mathrm{CH})$. The specific gravity of the soil is 2.68 . The gradation of the soil shows that more than $75 \%$ is silt and clay $(\mathrm{d}<0.075), 5 \%$ is fine sand $(0.075<\mathrm{d}<0.46 \mathrm{~mm}), 15 \%$ is medium sand $(0.46<\mathrm{d}<1.06 \mathrm{~mm})$, is $10 \%$ coarse sand $(1.06<\mathrm{d}<4.75 \mathrm{~mm})$, and less than $5 \%$ is gravel. The liquid limit and plastic limit of the soil sample are $66.5 \%$, and $32.3 \%$.

The bagasse ash is collected from Madukismo Sugar Mill, Bantul, in the Special Region of Yogyakarta. It is non-cohesive fine residue and classified as non-hazardous, non-plastic waste material. The specific gravity is 2.05 , which is less than that of normal soil. The grain size distribution of the bagasse ash shows that $1.5 \%$ is clay size, $72.9 \%$ is silt, $17.9 \%$ is fine sand and the rest is medium sand (Fig. 1). The result of chemical analysis of the bagasse ash indicated $51 \% \mathrm{SiO}_{2}, 17.4 \% \mathrm{Al}_{2} \mathrm{O}_{3}, 4.9 \% \mathrm{Fe}_{2} \mathrm{O}_{3}, 6.3 \% \mathrm{CaO}, 1.4 \% \mathrm{MgO}, 0 \% \mathrm{SO}_{3}, 2.3 \%$ $\mathrm{K}_{2} \mathrm{O}, 2.6 \% \mathrm{Na}_{2} \mathrm{O}, 2.1 \% \mathrm{H}_{2} \mathrm{O}$, and $1.8 \%$ loss of ignition (LI).

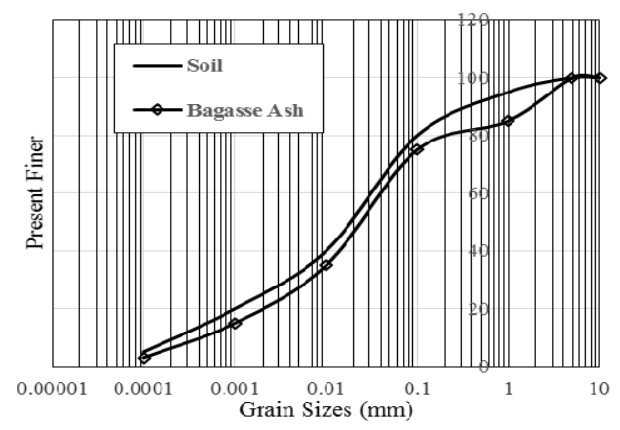

Fig. 1. Grain size distribution.

The calcium carbide residue used in this research was collected from Sedayu manufacturer of acetylene gas located in Bantul Regency, the Special Region of Yogyakarta. Its chemical content obtained from chemical analysis is as follows: $0.34 \%$ $\mathrm{SiO}_{2}, 2.21 \% \mathrm{Al}_{2} \mathrm{O}_{3}, 0.97 \% \mathrm{Fe}_{2} \mathrm{O}_{3}, 60.2 \% \mathrm{CaO}, 0.15 \% \mathrm{MgO}, 0.11 \% \mathrm{SO}_{3}, 1.46 \% \mathrm{~K}_{2} \mathrm{O}$, $0.08 \% \mathrm{Na}_{2} \mathrm{O}$, and $1.4 \% \mathrm{H}_{2} \mathrm{O}$. 


\section{Experimental program}

\subsection{Lime fixation point}

The lime fixation point (LFP) is the proportion of calcium carbide added to the soil that results in the maximum plastic limit. If the proportion of calcium carbide is increased, the plastic limit of the soil remains constant or decreases. The proportion of calcium carbide used in this study is $2 \%\left(\mathrm{w}_{\mathrm{P}}=21 \%\right), 4 \%\left(\mathrm{w}_{\mathrm{P}}=23.5 \%\right), 6 \%\left(\mathrm{w}_{\mathrm{P}}=23.3 \%\right), 8 \%\left(\mathrm{w}_{\mathrm{P}}=\right.$ $23.1 \%)$, and $10 \%\left(\mathrm{w}_{\mathrm{P}}=23 \%\right)$, so the LFP was found to be $4 \%$. In some practical assumptions, the added proportion of calcium carbide is LFP + (3 to 6\%). This study used $4 \%, 7 \%$, and $10 \%$ calcium carbide, whereas the percentage of bagasse ash used was $9 \%[8]$.

\subsection{Compaction}

In general, all samples used in this study were prepared at the maximum dry density (MDD) and optimum moisture content (OMC) obtained from standard Proctor compaction tests as indicated in Fig. 2. The effects of MDD and OMC on the shear behaviour of the calcium carbide-fly ash stabilized soil was also analyzed. In this study, soil samples were also prepared with water content more than and less than their optimum moisture content. It was indicated that the addition of bagasse ash to the soil resulted in a decrease of the optimum moisture content and a reduction of the maximum dry density compared to unstabilized soil.

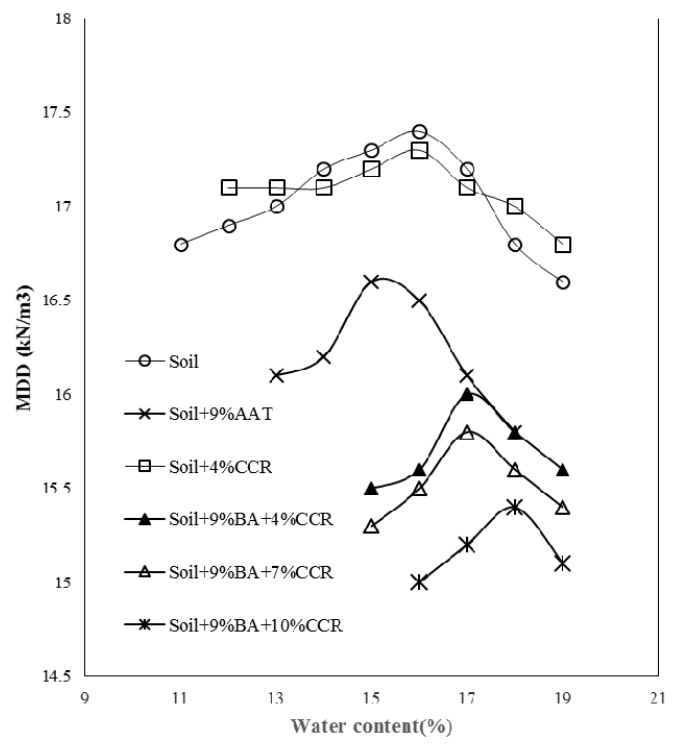

Fig. 2. Compaction curves.

\subsection{Unconfined compression and split tensile tests}

The specimens for both the unconfined compression and split tensile tests were compacted into a cylindrical mould in the condition of dry density and optimum moisture content. The cylindrical sample dimensions were $38 \mathrm{~mm}$ in diameter and $76 \mathrm{~mm}$ high. Then the samples 
were wrapped in polybags and stored in a humid chamber. The curing times adopted were $7,14,28,36,56$ and 100 days for both the unconfined compression and split tensile tests.

\subsection{Three-axial test}

As for both the unconfined compression and split tensile tests samples, the dimensions of the samples for the three-axial test were $36 \mathrm{~mm}$ in diameter and $76 \mathrm{~mm}$ high. All specimens were moulded at their dry density and optimum moisture content. Confining pressures applied to the specimens were 20,50 , and $100 \mathrm{kPa}$, which are coherent with practical conditions in engineering applications. For this test, 28 days was the curing time for all specimens.

\section{Results and discussion}

\subsection{Unconfined compression and split tensile tests}

The influences of the curing period and the proportion of calcium carbide residue on both the unconfined compression and tensile strength of bagasse ash-calcium carbide residue stabilized soil is presented in Figs. 3 and 4. These figures indicate that the curing period is a major factor influencing the shear behaviour of bagasse ash-calcium carbide stabilized soil.

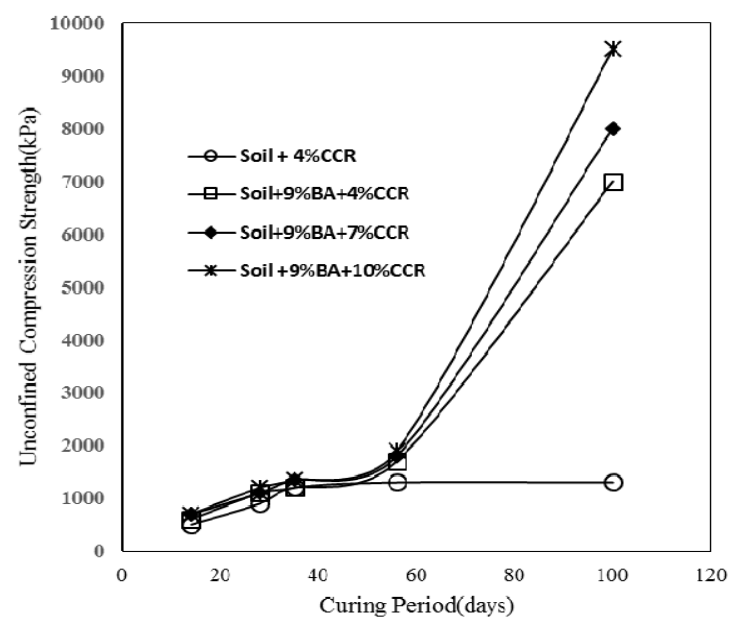

Fig. 3. The effect of curing period on unconfined compression strength.

A short curing period does not show any improvement of the unconfined compression or split tensile strength of the stabilized soil. It is interesting to note that, in the short term, there just occurs a cation exchange reaction. The reaction happens when $\mathrm{Ca}^{++}$in the calcium carbide replaces the positions of $\mathrm{Na}^{+}$and $\mathrm{K}^{+}$in the soil and results in flocculationagglomeration. This reaction is very fast, and only reduces the plasticity index, but does not change the shear stress parameters of the stabilized soil. In a long curing period, after 60 days, however, there is a significant improvement of both the unconfined compression and split tensile strength of the stabilized soil due to the chemical pozzolanic reaction between bagasse ash-soil and the lime in the calcium carbide. The formation of calcium silicate hydrate (C-S-H), which is the first stage of the pozzolanic reaction, takes place after 36 days of curing. Furthermore, the gain of unconfined compression and split tensile strength 
is dependent on the curing temperature [20]. Accordingly, for curing temperatures varying from 20 to $65^{\circ} \mathrm{C}$, the induction period varies from 4.8 hours to 75 days. In general, Figs. 3 and 4 indicate that the increase in both the unconfined compression and split tensile strength were strongly affected by the amount of calcium carbide.

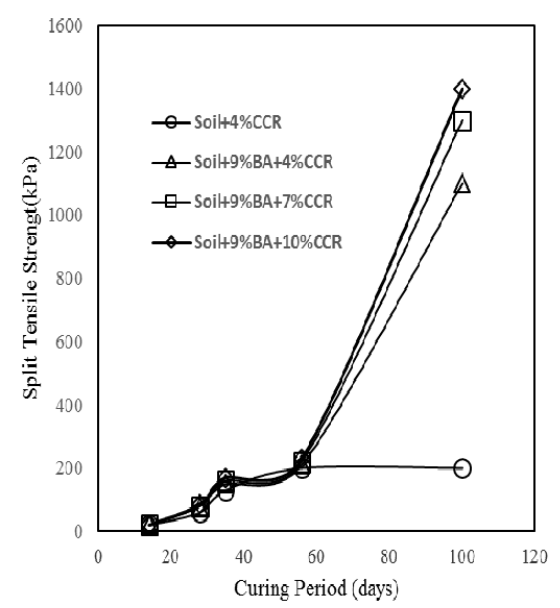

Fig. 4. The effect of curing time on split tensile strength.

\subsection{Three-axial tests}

Fig. 5 is the comparison between the typical axial strain and volumetric strain response for all the compacted samples, for $20 \mathrm{kPa}$ confining pressure and a 28-day curing period. The calcium carbide-soil mixtures were moulded at maximum water content (OMC) and maximum dry density (MDD). Fig. 5 indicates that the behaviour of the calcium carbidesoil mixtures was dramatically affected by the addition of calcium carbide residue. This can be seen from the changes of peak strength and stiffness of the stabilized soil. The comparison of compacted soil and compacted soil plus $9 \%$ bagasse ash shows that the partial replacement of soil by bagasse ash did not significantly influence the stress-strain behaviour, as can be seen from the changes of peak strength and initial stiffness. Although the gradation of bagasse ash is slightly different from that of the original soil, the replacement of soil by $9 \%$ bagasse ash did not result in an essential change in the properties of the bagasse ash-soil mixtures. The addition of calcium carbide to the soil, however, changes the peak strength, stiffness and brittleness of the calcium carbide-soil mixture. The significant gain of peak strength and stiffness can be seen from the combined effect of calcium carbide and bagasse ash. The peak shear strength of the calcium carbide-bagasse ash-soil mixtures is $720 \mathrm{kPa}$, compared to that of soil $(90 \mathrm{kPa})$, soil plus $9 \%$ bagasse ash $(120 \mathrm{kPa})$, and the calcium carbide-soil mixture $(250 \mathrm{kPa})$. These changes are due to the chemical pozzolanic reaction of silica $\left(\mathrm{SiO}_{2}\right)$ and alumina $\left(\mathrm{Al}_{2} \mathrm{O}_{3}\right)$ in bagasse ash and the calcium $(\mathrm{CaO})$ in calcium carbide. The new formations from this reaction are calcium silicate hydrate $(\mathrm{C}-\mathrm{S}-\mathrm{H})$, calcium aluminate hydrate $(\mathrm{C}-\mathrm{A}-\mathrm{H})$, and/or calcium aluminate silicate hydrate (C-A-S-H). The brittleness of bagasse ash-calcium carbide stabilized soil is extremely reduced and is also followed by the reduction of axial strain. 

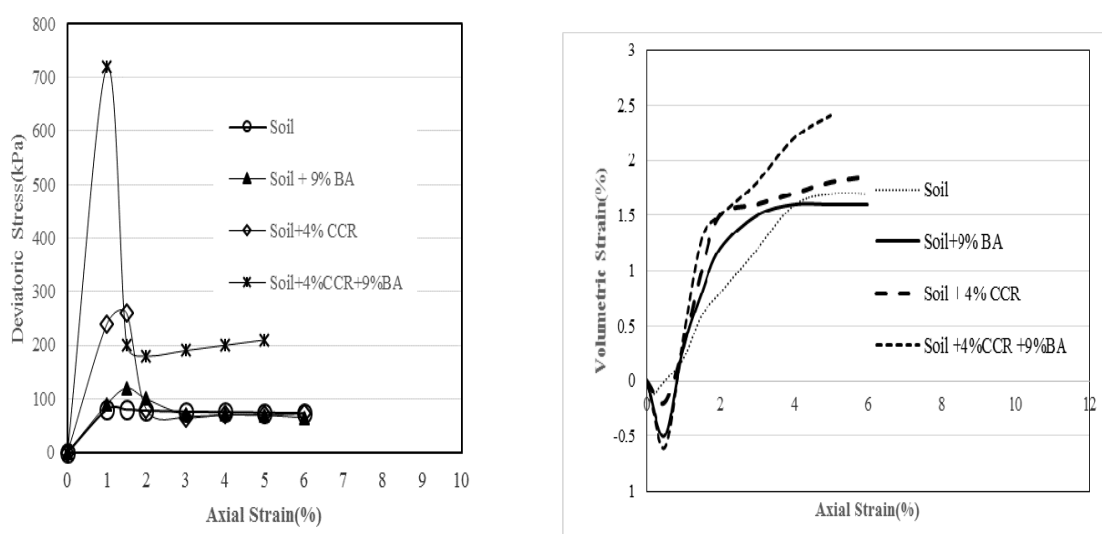

Fig. 5. Stress-strain response and volumetric-axial strain of compacted stabilized soil: $20 \mathrm{kPa}$ confined pressure and 28-day curing time.

In Fig. 5, the behaviour of all the specimens tested in the three-axial apparatus for volumetric-axial strain curves are similar. The compressive response is followed by the maximum expansion value close to the peak shear strength. Furthermore, the ductility of all the samples decreases as the soil approaches the critical state, and it seems that the compressive strength is influenced by the calcium carbide residue and bagasse that was added to the soil.

To study the effects of the compaction parameters on the behaviour of bagasse ashcalcium carbide residue stabilized soil, a series of three-axial experiments were performed on the compacted stabilized soil. The soil samples were compacted at the optimum moisture content (OMC), as well as at less than and more than the OMC. Figs. 6 and 7 show the deviatoric stress-axial strain, and volumetric-axial strain response on the specimens for the confining pressure of $20 \mathrm{kPa}$ for the specimens without curing time. Higher stiffness is observed for the samples moulded with water content less than their $\mathrm{OMC}$, whereas lower stiffness is seen in the samples compacted with water content more than their OMC. These phenomena indicate that the compaction parameters are fundamental factors for stabilized soil after cementation. Similar behaviour is seen in the specimens with the 28-day curing time.

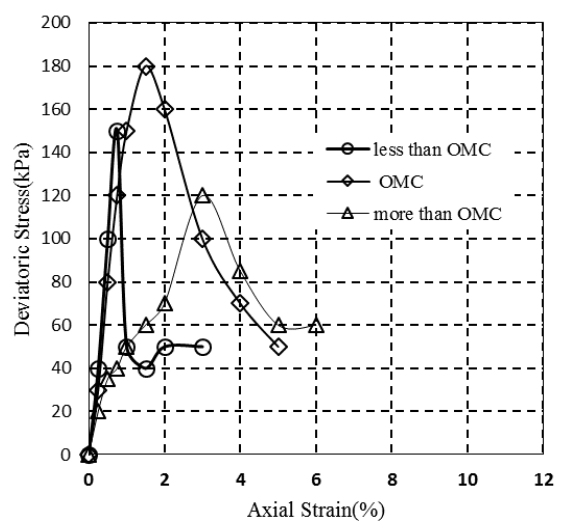

Fig. 6. Axial strain response for uncured compacted samples. 


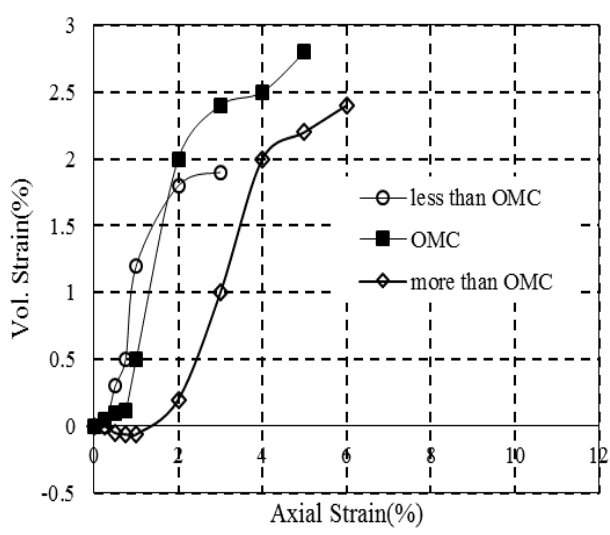

Fig. 7. Volumetric-axial strain for uncured compacted samples.

The uncured specimens moulded at the OMC show the highest shear strength. In the specimens with the 28-day curing, however, the shear strength was higher for those compacted with less than their OMC. Therefore, the shear behavior of bagasse ash-calcium carbide residue stabilized soil samples was stronger and stiffer when they were moulded with less than their OMC and 28 days of curing time, or with their optimum moisture content without any curing. This finding may be due to compaction factors, mainly the maximum dry density and optimum water content, before the pozzolanic reaction started, and due also to gel formation after the development of the pozzolanic reaction.

\section{Conclusions}

A series of experiments were carried out on original soil, calcium carbide stabilized soil, and bagasse ash-calcium carbide stabilized soil compacted with its optimum water content, and less than and more than its optimum water content. The results of the investigation can be summarized as follows:

1. The addition of calcium carbide residue significantly increased the shear strength and stiffness of the calcium carbide stabilized soil.

2. The addition of bagasse ash to calcium carbide soil was required to meet the short- term and long-term pozzolanic reaction.

3. The curing time, curing temperature and compaction parameters significantly influence the stress-strain behaviour of carbide-lime-bagasse ash stabilized soil.

4. The unconfined compression and split tensile strength of calcium carbide-bagasse ash stabilized soil was significantly improved with 56 days curing time, which may be due to the long-term pozzolanic reaction.

5. Based on the three-axial compression test, the maximum stiffness and shear strength of carbide-lime-bagasse ash soil mixtures occurred in stabilized soil specimens compacted with their optimum water content. After 28 days of curing, however, there was an improvement of the stiffness and shear strength in the stabilized soil samples compacted with less than their optimum water content.

The writers wish to express their gratitude to Lembaga Penelitian dan Pengabdian Pada Masyarakat (LPPM) Universitas Atma Jaya Yogyakarta for the financial support to the research group to complete the research. 


\section{References}

1. J.T. Hatmoko, Y. Lulie, Proc. Konferensi Nasional Teknik Sipil Ke-1, Universitas Atma Jaya Yogyakarta, 101-109 (2007)

2. J.T. Hatmoko, Y. Lulie, Proc. Konferensi Nasional Teknik Sipil Ke-2, Universitas Atma Jaya Yogyakarta, 123-130 (2008)

3. F. Diane, TugasAkhir S-1, Prog. Studi Teknik Sipil Universitas Atma Jaya Yogyakarta

4. W. Diana, A.S. Muntohar, Proc. Konferensi Nasional Teknik Sipil Ke-6, Universitas Trisakti Jakarta, 33-37 (2012)

5. W. Diana, A.S. Muntohar, Proc. Konferensi Nasional Teknik Sipil Ke-7, Universitas Sebelas Maret Surakarta, 69-75 (2013)

6. M. Thalib, G.M. Bakole, J. Geotech. Geo-env. Engrg. ASCE 16, 983-996 (2011)

7. L. Yadu, R. K. Triphati, Int. J. Earth Sci. Engrg. 4, 42-45 (2011)

8. J.T. Hatmoko, H. Suryadharma, Research Report, Universitas Atma Jaya Yogyakarta (2016)

9. J.K. Mitchel, R.K. Katti, Proc. $10^{\text {th }}$ Int. Conf. on Soil Mech. and Found. Engrg., International Society of Soil Mechanics and Foundation Engineering, London, 261317 (1981)

10. D.N. Little, M.R. Thompson, R.L. Terrel, J.A. Epps, E.J. Barenberg, Rep. No. ESLTR-86-19, Air Force Engineering and Services Center, Tyndall Air Force Base, Fla. (1986)

11. M. Kamon, S. Nontananandh, J. Geotech. Engrg. ASCE, 117, 3-17 (1991)

12. M.H. Maher, J.M. Butziger, D.L. DiSalvo, L.S. Oweis, Fly Ash Improvement, Geotech. Spec. Publ. No. 36, ASCE, New York, 73-88 (1993)

13. S. Horpibulsuk, C. Phetchuayi, A. Chinkulkijniwat, J. Mtls. in Civ. Engrg. ASCE, 24, 184-193 (2012)

14. S. Nontananandh, M. Kamon, Proc, $2^{\text {nd }}$ Intl. Conf. on Envir. Geotechnics, Balkema, Rottedam , 857-852 (1998)

15. C. Jatruapitakkul, B. Roongreung, J. Mtls. in Civ. Engrg. ASCE, 15, 470-475

16. Y. Li, and Y. Hu, Adv. Mtls. Res. 33, 553-558 (2008)

17. A. Kampala, S. Horpibulsuk, J. Mtls. in Civ. Engrg. ASCE, 25, 37-47 (2013)

18. N. Makarat, C. Jaturapitakkul, J. Mtls. in Civ. Engrg. ASCE, 22, 1164-1170 (2010)

19. K. Somna, C. Jaturapitakkul, J. Mtls. in Civ. Engrg. ASCE, 23, 298-305 (2010)

20. S. Horpibulsuk, J. Mtls. in Civ. Engrg. ASCE, 125, 471-476 (2013) 